of the tuhes, and some eren regard the contractions of their lumen as secondary in importance. Virchow assigns as a cause peritonitis and preudo. memhranous adhesions with constriction of the affected tuha. Spiegelherg speaks of swelling of the tuhal mucous memhrane and ohstrnctive collection of secretions. Kloh mentions hernia of the mucous memhrane and consequent arrest of peristalsis; or polyps of the uterine end may ohstruct the oyum in its passage. It is also said that deficient, or ahsent, motion of the cilis is a cause of delny in the prasage of tha ovum, so that it finally grows too large for further progress. Any or all of these canses may at times he present, hut they are not sufficient to account for $n$ douhle recurrent tuhal gestation. An ahnormal formatiou of the tuhe, due to defect in emhryonic development is the common source, and it affects hoth tuhes equally. Freund's researches have shown that the tuhes, after the union of the middle parts of Mrüller's duets has formed the uterns, show a spiral, corkscrewlike iwist, in rolving the whole tuhe. This occurs during the descent of the duct. When this has renched its greatest length, the turns hegin to smooth themselves laterally from the uterus. These turns may remain as a permenent arrest of derelopment, the snrroundings heing in no way involved and no trace of perisalpingitis or pelviperitonitis can be found. The condition may he often seen in the hodies of children. Thus nny healthy woman is liahle to a tuhal pregnancy from her tuhes remaining in an in. fantile state and the pregnancy be physiological. Again, tbe tuhal canal does not al ways ran in the middle of the tuha cylinder; its coursa may ha most derious, approsching and receding from the surfaca of tha tuhe, which thus having walls of unequnl thicleness and resistance, tha growing ovum distends it at the point of lesst resistance, and may thus be arrested in its progress. Another antecedent cause may ha found in the so-called direrticulam of the tuhal cannl. The ovum may ba entangled therein. To establish a diagnosis of singla or recurrent tuhal pregnancy, specinl imporLanca attaches to the extension of a decidua from tha uterus, though its absenca is no proof that the gestation dnes not exist. A microscopic examination of the membrane is essential, though it is not certsin that from it its extra-uterine character can he determined certainly. In various conditions memhranes are thrown off from the uterus, thus: 1st. In extra-nterine pregnancy. 2d. Dysmenorrhoes memhranscea. 3d. In intra.uterine pregnancy with abortion. In the first, the cellular part of the gland layer is fully differentiated, the inner layer is extended, the outer remains in the nterus. In the second, all the elements of the sormal mucous memhrane are cast off. On its surface is normal epithelium; the deep glands have their epithelium unaltered. All sorts of cells are found in their connecting tissues, and foci of infiltration ahound. In the third, one finds either ovular dehris or memhranes showing the unmistakahle evidences of pregnancy. The chief difference hetween the decidua of extra-uterine pregnancy and thnt of dymmenorrhœic memhrane lies in the presence or ahsence of glands.

The treatment of this condition is laparotomy and removal of the sse. At the time the other tuhe should he examined, and if found to he spiral or twisted it should also be removed. Neither injection of the sac nor electro-puncture gives any positive sssurance that suhsequent rupture and hemorrhage may not occur. 


\title{
UTERUS SERBEPTCS.
}

Cepinskx (Centrallulat für Gynākologie, 1893, No. 33) reports the details of an interesting case of a double vagina in a woman tiventy-gix years of age. Menstruation regular. On examination the external genitals were found normal. The introitus vagins was not median, but by the side of the right lahium majus. Hymen gone. Near the introitus was discovered a second opening $50 \mathrm{~mm}$. hroad, surrounded by $\mathfrak{n}$ fringe of mucous memhrane, through which a sound was passed into a second vagina, nurrower than the first, hnt otherwise perfect. From either a sound could he introduced into the uterus, each vagina having $n$ separate and perfect portio vnginm uteri. Wbether the division that completely вeparated these vaginm extended throughout the uterine cavity conld not he determined. The uterus was of normal size. Coitus easy and normnl. A year later the pntient returned for nd vice, complnining of irregular hemorrbage from the genitals nccompnnied hy uterine pnin. Had not menstrunted for ten weeks. Examination sbowed the old anomaly with hleeding from the small opening of the left vaginn. In the right vngina the os was open and there was hemorrbnge therefrom. As the vaginal vault was pressed with the speculum a segmeot of fortal memhrane was ohserved to pass out of the os. Corpus uteri enlarged nnd soft. Ahortion occurred on the following day, the ovum being the size of $\mathbf{n}$ plum, and in it ao embryo turee centimetres $\log$ was fouod. Ten days after the ahortion, for experiment, milk was injected through the left cervix into the uterine cavity aod this was ohserved to flow out through the right os.

\section{GTIOOLOGY.}

\author{
UNDER THE CEABGE OE
}

HENRY C. COE, M.D., M.R.C.S., , or NRE YORE.

\section{The Curative Effect of Cceliotosy on Peritoneal Tuberculosib.}

Warnek (Centralblalt für Gynäkologie. 1893, No. 50), after reviewing all the evidence in faror of the cure of tuherculous peritonitis by simple nhdominal incision, with or without drainage, arrives at the conclusion thnt whenerer the carity is opened the peritoneum undergoes a certain nmount of irritntion, due to the cbange in its pbysiological condition caused by the entrance of nir and the lowering of its normal temperature. In the case of various manipulations of the ahdominal contents, hy irrigation, sponging, the separation of adhe. sions, etc., an ndditional element of irritation is introduced, wbich is manifested not only hy congestion of the serous surface, hut hy the subsequent formation of adhesions, whicb may in time he entirely nhsorbed, as shown hy secondary operations. It is well known tbat in cases of ascites due to secondary papillary or carcinomntous growths on tbe peritoneum, the fluid may 
quicl-ly reaccumulate after several tappings, but when an exploratory incision is made this may not occur, although the conditions remain unchanged. Hence the following conclusions may he drawn: $\Delta$ fter the ahdomen has been opened in $\mathrm{a}$ case of tuhercnlosis and the peritoneum has heen irritnted hy manipulation, $n$ plastic exidnte is thrown out and adhesions are formed. Provided that no conditions are present favorahle to their further development, the hacilli are destroyed by this exndate nnd the tuhercles undergo fihrous degenerntion. In the course of time the exndate is ahsorhed and a cure of the disense results.

\section{New Method of Treativa Peritoneal toberculosie.}

NoLEx (Berliner klin. Wochenschrift, 1893, No. 24), heing convinced that the favorahle results ohserved after coliotomy are due to the simple contact of air with the peritoneum, has conceived the idea of introducing nir into the ahdominnl carity through a needle. He reports three cases, two of which were successful. In these, repented tappings hnd heen employed, hut the ascitic fluid alwnys reaccumulated, until air was pumped in by mesns of an apparatus devised hy the writer. A third successful case is reported hy Hosetig-Moorhof.

\section{Treatment of Sterihtty.}

Seetigaran (Jünehener med. Wochensehrift, 1893, No. 45) has fonnd that in his experience the hushand is in fault in 75 per cent. of the sterile marriages, through azoōsyermia due to douhle epididymitis. That the latter condition is not necessarily hopeless was shown by the reappenrance of living apermatozon in the semen after treatment. He recommends the active treatment of gonorrhoal epididymitis as soon as possible nfter the inflammatory stage, with a view to prevention.

The application of gal vanism to the cervical endometrium is often successful, as well as the use of the faradic currest in cases where there is entire absence of sexual response on the purt of the female.

\section{The action of Salicy iac acid on the Uterde.}

Bivz (Berliner klin. Wochensehrift, 1893, No. 41) states that galicylate of sodium has a heneficinl effect in cases of dysmenorrhosa nud scanty menstruation not due to chlorosis. In gouty subjects it is indicated in cases of mellorrhagia, as well as in patients who nre prone to early ahortion.

\section{VAOINo-pixation OF THE UTERTE.}

KNoRre (Centralblalt für Gynäkologie, 1893, No. 51), in an extend ed article, reports the results of a series of twenty-four cases opernted upon in Küstner's clinic according to Mackenrodt's method. Of these only nine were entirely successful. He regards the operation as indicated in all cases of retroversion with a movahle uterus that cannot he kept in position hy a pessary, especially when there are accompanying lncerations of the cervix and perineum; also when the patient cannot tolerate a peasary. It is contra-indicated in 
prolnpsus, in retroflexion with fixation, nod in crses in which n cure can he expected with a pessary.

\section{New Operation for SteNogis OF the Os Uteri.}

Pozzl (Annales de Gynécologie et dr Obaldrique, Decemher, 1893) describes the procedure thus: He frat divides the cervix on hoth sides with scissors, then excises a wedge from each flnp on either aide of the canal - four in all. The mucous memhrnne of the vaginn is united to the mucosa of the cervical canal with silver-wire sntures in such a way as to close the four raw surfaces. The result is a condition similar to that of an ordinsry bilateral laceration, hut without the formation of cicatricial tissue and the disturhances to which thig gives rise.

\section{Fibroaryoma of the Ovary or Bhoad hioanent.}

Delsoranoe (Archives de Tocologie et de Gynecologie, 1893, No. 12) reports a case of fbromyoma of the ovnry weighing nearly seven pounds. The tumor was adherent nnd the pedicle was twisted several times ahout its long axis. On section the growth showed hemorrhagic softening. There was some douht as to whether it originated in the ovary or in the hroad ligament. The writer gives the histories of six reported cases of pedunculated fihromyoma of the hroad ligament, from which he makes the following deductions: Ascites was seldom present to any extent. In most cases the tumor grew rapidly and was accompanied hy severe pain, prohahly due to the presence of adhesions. The differential diagnosis from ovarian fibroma, or even from pedunculnted uterine fibroid is practicslly impossible. The surgical treatment of these neoplasms presents no special features.

\section{Pgeddo-jenbraxodg Exteritis frou a Gynecolooical Standpoist.}

Moxon (Ibid.) concludes an article on this snhject as follows: 1. Pseudomemhranous enteritis is frequently ohserved in connection with disease of the uterus and adnexa. 2. It affects the large intestine and gives rise to chronic constipation with colicly pains. 3. It mny coexist with membranous dysmenorrhaes. 4. Sometimes it seems to he due to compression of the rectum hy the retroflexed uterus. 5. In some instances it seems fair to infer thnt it is the result of the extension of an inflammntory process from the uterus or peri-uterine tissues. 6. The possihility of its existence should he horne in mind in all cases of intractahlc ahdominnl pain in patients with pelvic trouhle. A careful study of the symptoms will show that these are often dne not to disease of the uterus or adnexa, hut to the intestinal tract.

\section{TREATMENT OF IFFLiAMATION OF THE ADFEXA.}

J $\Delta$ Cons, of Brussels (Ibid.), reports eighty $\cdot s i x$ cases of cœliotomy for disease of the adnexn, with five deaths; and one hundred and forty cases of vaginal extirpation of the nterus, with disessed tuhes and ovaries, with only two deaths. In the former series the resnlt was only partly successfnl in thirty cases, while in the latter he obtained $n$ cure in one hundred and 